\title{
Is there any contribution of bronchial washing to biopsy in the diagnosis of patients with endobronchial pathology in the era of personalized medicine?
}

\author{
Oğuz KARCIOĞLU ${ }^{1}(I D)$ \\ Sevinç SARINÇ \\ ULAŞLI $^{1}$ (ID) \\ Elif BABAOĞLU ${ }^{1}(I D)$ \\ Emine KELEŞ ${ }^{2}(I D)$ \\ Ümran ÖZDEN \\ SERTÇELIK ${ }^{3}$ \\ Sevgen ÖNDER ${ }^{4}(I D)$ \\ Deniz $\mathrm{KÖKSAL}^{1}$ (ID)
}

${ }^{1}$ Department of Pulmonary Diseases, Hacettepe University Faculty of Medicine, Ankara, Turkey

${ }^{1}$ Hacettepe Üniversitesi Tıp Fakültesi, Göğ̈̈s Hastalıkları Anabilim Dalı, Ankara, Türkiye

${ }^{2}$ Clinic of Pulmonary Diseases, Susehri State Hospital, Sivas, Turkey

${ }^{2}$ Suşehri Devlet Hastanesi, Göğüs Hastalıkları Kliniği, Sivas, Türkiye

${ }^{3}$ Clinic of Pulmonary Diseases, Ankara City Hospital, Ankara, Turkey

${ }^{3}$ Ankara Şehir Hastanesi, Gögüs Hastalıkları Kliniği, Ankara, Türkiye

${ }^{4}$ Department of Pathology, Hacettepe University Faculty of Medicine, Ankara, Turkey

${ }^{4}$ Hacettepe Üniversitesi Tıp Fakültesi, Patoloji Anabilim Dalı, Ankara, Türkiye
Cite this article as: Karcıoğlu $O$, Sarınç Ulaşlı $S$, Babaoğlu E, Keleș E, Özden Sertçelik Ü, Önder S, et al. Is there any contribution of bronchial washing to biopsy in the diagnosis of patients with endobronchial pathology in the era of personalized medicine? Tuberk Toraks 2021;69(3):307-313.

\section{Address for Correspondence (Yazışma Adresi)}

\section{Dr. Oğuz KARCIOĞLU}

Hacettepe Üniversitesi Tıp Fakültesi,

Göğüs Hastalıkları Anabilim Dalı,

ANKARA - TÜRKIYE

e-mail: oguzkarcioglu@gmail.com

CCopyright 2021 by Tuberculosis and Thorax.

Available on-line at www.tuberktoraks.org.com

\begin{abstract}
Is there any contribution of bronchial washing to biopsy in the diagnosis of patients with endobronchial pathology in the era of personalized medicine?

Introduction: Bronchoscopic biopsies and bronchial washings (BW) are commonly used together for the diagnosis of centrally located tumors. This study aimed to investigate the clinical relevance of routinely collecting BWs in patients who simultaneously had biopsies for visible endobronchial lesions in the current molecular analysis-driven personalized medicine era.
\end{abstract}

Materials and Methods: We retrospectively reviewed the patients who underwent fiberoptic bronchoscopy (FOB) between October 2011 and December 2016. Patients who had both BW and biopsy specimens (EBB: endobronchial forceps biopsy and/or EBNA: endobronchial needle aspiration biopsy) for visible endobronchial lesions were included in this study. Demographic and clinical data, macroscopic findings during FOB, pathology results, and final diagnoses were collected from the hospital database.

Results: The study included 269 patients (220 males/49 females) with a mean age of $61.6 \pm 10.6$ years. While the overall diagnostic yield of FOB was $71.4 \%$, the diagnostic yields of bronchoscopic procedures were $68.2 \%$ for $E B B, 83.3 \%$ for EBNA, and $19.7 \%$ for BW. Only three patients (1.1\%) with undiagnostic biopsies had positive BW cytology revealing merely malignant epithelial cells 
Conclusion: BW provided a negligible diagnostic contribution in $1.1 \%(n=3)$ of the patients. These three patients had undergone further diagnostic procedures for making a proper therapeutic management plan. In the era of personalized therapy, it is logical to obtain more biopsy in the time spent for BWs.

Key words: Endobronchial lesion; bronchial washing; fiberoptic bronchoscopy; biopsy; diagnosis

\section{ÖZ}

Kişiselleştirilmiş tedavi çağında endobronşiyal patolojili hastaların tanısında bronşiyal yıkamanın biyopsiye katkısı var mı?

Giriş: Bronkoskopik biyopsiler ve bronşiyal yıkamalar (BY) santral yerleşimli tümörlerin tanısında yaygın olarak birlikte kullanılmaktadır. Bu çalışma, kişiselleştirilmiş tıp çağında, görülebilir endobronşiyal lezyonlar için biyopsi alınan hastalarda rutin olarak BY alınmasının tanıya katkısını araştırmayı amaçlamaktadır.

Materyal ve Metod: Ekim 2011 ile Aralık 2016 arasında fiberoptik bronkoskopi (FOB) yapılan hastalar geriye dönük olarak incelenmiştir. Görülebilir endobronşiyal lezyon için hem BY hem de biyopsi örnekleri (EBB: endobronşiyal forseps biyopsisi ve/veya EBNA: endobronşiyal iğne aspirasyonu) olan hastalar bu çalışmaya dahil edilmiştir. Hastane veri tabanından demografik ve klinik veriler, FOB sırasındaki makroskopik bulgular, patoloji sonuçları ve son tanılar toplanmıştır.

Bulgular: Çalışmaya katılan 269 hastanın (220 erkek/49 kadın) yaş ortalaması 61,6 \pm 10,6 yıl olarak bulunmuştur. FOB'nin genel tanısal katkısı \% 71,4 iken, bronkoskopik işlemlerin tanısal katkıları EBB için \%68,2; EBNA için \%83,3 ve BY için \% 19,7 olarak saptanmıştır. Sadece üç hastada $(\% 1,1)$ biyopsi tanısal olmamasına rağmen, BY sitolojisinde malign epitel hücreler görülmüştür.

Sonuç: BY'nin tanısal katkısı ihmal edilebilir düzeydedir $(n=3)(\% 1,1)$. Bu üç hastanın tanısı, uygun bir terapötik yönetim planı yapmak için daha ileri tanısal yöntemleriyle teyit edilmiştir. Kişiselleştirilmiş tıp çağında, BY'ler için harcanan zamanda daha fazla biyopsi almak uygun görünmektedir.

Anahtar kelimeler: Endobronşiyal lezyon; bronşiyal yıkama; fiberoptik bronkoskopi; biyopsi; tanı

\section{INTRODUCTION}

Fiberoptic bronchoscopy (FOB) is an essential tool for the diagnosis of centrally located lung tumors. It provides obtaining pathological specimens via endobronchial forceps biopsy (EBB) and cytological specimens such as endobronchial needle aspiration biopsy (EBNA) from the tumor, transbronchial needle aspirations (TBNA) from mediastinal lymph nodes, bronchial brushings, bronchial washing (BW), and bronchoalveolar lavage.

It is evident that EBB is the most commonly used and most valuable method for diagnosing visible endobronchial lesions with a diagnostic utility of $71 \%$ $95 \%(1-7)$. Although it is accepted that the combination of procedures increases the diagnostic yield up to $85 \%-98 \%$, the issue of optimal combination is still controversial $(1-3,6,8)$. The diagnostic value of BW, which is the most frequently used material for cytological analysis, is between $32 \%$ and $90 \%$ in patients with visible endobronchial lesions (1,5,6,9-12). Although many studies have advocated the routine use of BW with EBB considering that diagnostic yield increases up to $20 \%$, there are also studies supporting the opposite $(1,2,7,9,12,13)$.

During the last two decades, much progress has been made in lung cancer research and personalized therapy. Targeted therapies for specific tumor mutations and immunotherapies are now extensively used to treat advanced non-small cell lung cancer (NSCLC) patients $(14,15)$.

Considering the molecular analysis-driven personalized medicine era, this study aimed to investigate the clinical relevance of routinely collecting BW, in terms of diagnostic yield and added value, in patients who simultaneously had biopsies (EBB and/or EBNA) for visible endobronchial lesions.

\section{MATERIALS and METHODS}

\section{Patients}

We retrospectively reviewed the patients who underwent FOB between October 2011 and December 2016 in our bronchoscopy unit. Patients who had both BW and biopsy specimens (EBB, EBNA, or both) for visible endobronchial lesions were included in this study. Demographic and clinical data, macroscopic findings during $\mathrm{FOB}$, pathology results, and final diagnoses were collected from the hospital database. The Clinical Research Ethics Committee of Hacettepe University approved the study (GO 17/252, 29.03.2017).

\section{Bronchoscopic Procedures}

Conventional diagnostic FOBs were all performed by experienced bronchoscopists and residents under 
their supervision. Lidocaine was used for local anesthesia as an oro-nasal spray before the procedure and instilled locally as needed. Sedation was provided with midazolam in selected patients. PENTAX EPK-I bronch-o-fiberoscope (PENTAX Medical, Japan) was used for all bronchoscopies.

We described "visible endobronchial lesion" as lesions extending from the mucosa to the lumen or irregularities infiltrating the mucosa, obstructing or narrowing the airway. We excluded the patients whose airways were constructively narrowed or compressed externally by the tumor.

We principally take at least five biopsies from each visible endobronchial lesion unless the procedure was not prematurely terminated due to complications such as bleeding, hypoxia, tachycardia, et cetera. EBNAs from the visible endobronchial lesion were commonly applied if the bronchoscopist had an impression that EBB might be inadequate for the exact diagnosis or the lesion was prone to bleeding due to hypervascularity. Two types of 22-gauge cytology needles (Wang MW-122 of Bard-Wang, Billerica, Mass., USA and Matek TBN0122 of Matek Medical, Ostim, Ankara, Turkey) were used for EBNAs. EBB specimens were fixed in 10\% formaldehyde solution, EBNA specimens were air-dried and sent to the cytology department and stained with May-Grünwald Giemsa. BWs were collected from the affected area by instilling $10-40 \mathrm{ml} 0.9 \%$ saline and aspirating it via the bronchoscope suction channel in small lavage traps. The collected material was centrifuged, and cytospin slides were prepared then stained with Pap Stain. The rapid-on-site cytological evaluation was not available. An experienced cytopathologist examined all materials. The presence of malignant cells defined positive BW cytology. The final diagnoses were based on all available pathologic information.

\section{Statistical Analysis}

Statistical analysis was conducted using the IBM SPSS Statistics for Windows, Version 23.0. Armonk, NY, USA: IBM Corp. Categorical variables were shown as frequencies and percentages. Numerical variables with a normal distribution were given as mean \pm standard deviation.

\section{RESULTS}

The study included 269 patients (220 males/49 females) with a mean age of $61.6 \pm 10.6$ years. We summarized the characteristics of patients in Table 1. Diagnostic yields of bronchoscopic procedures were $68.2 \%$ for $\mathrm{EBB}, 83.3 \%$ for $\mathrm{EBNA}$, and $19.7 \%$ for BW. The overall diagnostic yield was calculated as $71.4 \%$. Squamous cell carcinoma was the most common pathological diagnosis $(n=59,21.9 \%)$, followed by adenocarcinoma ( $n=47,17.5 \%), \operatorname{NSCLC}(n=40$, $14.8 \%)$ and small cell carcinoma $(n=29,10.8 \%)$.

Final diagnoses obtained from bronchoscopic procedures and diagnostic contributions of these bronchoscopic procedures are depicted in Table 2 and Figure 1. BWs were positive for malignant epithelial cells in 53 patients. While BWs indicated the subtypes of tumors in 28 patients, malignant epithelial cells were just seen in 25 patients. The biopsy (EBB and/or EBNA) findings of these 25 patients were NSCLC in eight, adenocarcinoma in seven, squamous cell carcinoma in four, and small cell carcinoma in three, and chronic inflammation in three patients. In other words, only three patients (1.1\%) who had a negative biopsy for a malignant tumor had malign epithelial cells in BW, proving the presence of a malign epithelial tumor. Additional interventions were performed for exact diagnosis in these three patients. A Tru-Cut biopsy from iliac bone lesion revealed adenocarcinoma metastasis in the first patient. Paracentesis cytology and cytoblock analysis revealed adenocarcinoma metastasis in the second patient, and a percutaneous biopsy from the pulmonary mass revealed NSCLC in the third patient.

\section{DISCUSSION}

The present study, which aimed to investigate the contribution of BW to biopsy (EBB and/or EBNA) in the diagnosis of patients with visible endobronchial lesions, showed that the diagnostic yield of BW was $19.7 \%$. Only three patients (1.1\%) with undiagnostic biopsies had positive BW cytology revealing merely malignant epithelial cells. Further diagnostic tests were performed to make a therapeutic management plan for these three patients.

The issue of routinely performing BWs in patients with visible endobronchial lesions is still controversial, and there are variabilities among different centers (8). A recent French study investigating the sensitivity of BWs obtained with conventional FOB in diagnosing lung malignancies has reported that the sensitivity is $22.9 \%$ in visible $(n=258)$ and $2.8 \%$ in non-visible tumors $(n=108)$. Only one patient received a diagnosis of malignancy solely based on 


\section{Table 1. The characteristics of study patients}

Number of patients

Mean age

Gender

Characteristics of visible endobronchial lesion

Lesion extending from the mucosa

Mucosal irregularity

Mucosal irregularity with external compression

Diagnostic yield of bronchoscopic procedures

Endobronchial forceps biopsy $(n=261)$

Endobronchial needle aspiration $(n=42)$

Bronchial washing $(n=269)$

Overall diagnostic yield of FOB

Final bronchoscopic diagnosis

Squamous cell carcinoma

Adenocarcinoma

Non-small cell carcinoma

Small cell lung carcinoma

Lymphoma

Carcinoid tumor

Breast carcinoma metastasis

Tiroid carcinoma metastasis

Choriocarcinoma metastasis

Neuroendocrine tumor

Malign epithelial cells on BW cytology*

*Final diagnosis of the patients with malign epithelial cells on BW cytology

Adenocarcinoma

Non-small cell carcinoma $\mathrm{n}=\mathbf{2 6 9}$

$61.6 \pm 10.6$ (Range: 22-86)

Male, $\mathrm{n}=220(81.8 \%)$

Female, $\mathrm{n}=49(18.2 \%)$

$$
\begin{gathered}
n=192(71.4 \%) \\
n=46(17.1 \%) \\
n=31(11.5 \%)
\end{gathered}
$$

\begin{tabular}{|c|c|c|c|}
\hline Diagnosis & $\begin{array}{l}\text { Endobronchial forceps biopsy } \\
\qquad(n=178)\end{array}$ & $\begin{array}{l}\text { Endobronchial needle } \\
\text { aspiration }(n=35)\end{array}$ & $\begin{array}{l}\text { Bronchial washing } \\
\qquad(n=53)\end{array}$ \\
\hline Non-small cell carcinoma & 37 & 11 & 9 \\
\hline Squamous cell carcinoma & 59 & 4 & 5 \\
\hline Adenocarcinoma & 44 & 8 & 9 \\
\hline Small cell carcinoma & 27 & 8 & 5 \\
\hline Malign epithelial cells & - & - & $25^{* *}$ \\
\hline Neuroendocrine tumor & - & 1 & - \\
\hline Carcinoid tumor & 2 & 3 & - \\
\hline Lymphoma & 4 & - & - \\
\hline Breast carcinoma metastasis & 3 & - & - \\
\hline Tiroid carcinoma metastasis & 1 & - & - \\
\hline Choriocarcinoma metastasis & 1 & - & - \\
\hline \multicolumn{4}{|c|}{$\begin{array}{l}\text { *Bronchial washings were positive for malign epithelial cells in only } 3 \text { patients whose biopsies were undiagnostic. Additional biopsies performed } \\
\text { for exact diagnosis. } \\
¥ \text { The biopsy findings in these patients were NSCLC: } 8 \text {, Adenocarcinoma: } 7 \text {, Squamous cell carcinoma: 4, Small cell carcinoma: } 3 \text {, Chronic } \\
\text { inflammation: } 3 \text {. }\end{array}$} \\
\hline
\end{tabular}

Table 2. Final diagnoses obtained from bronchoscopic procedures 


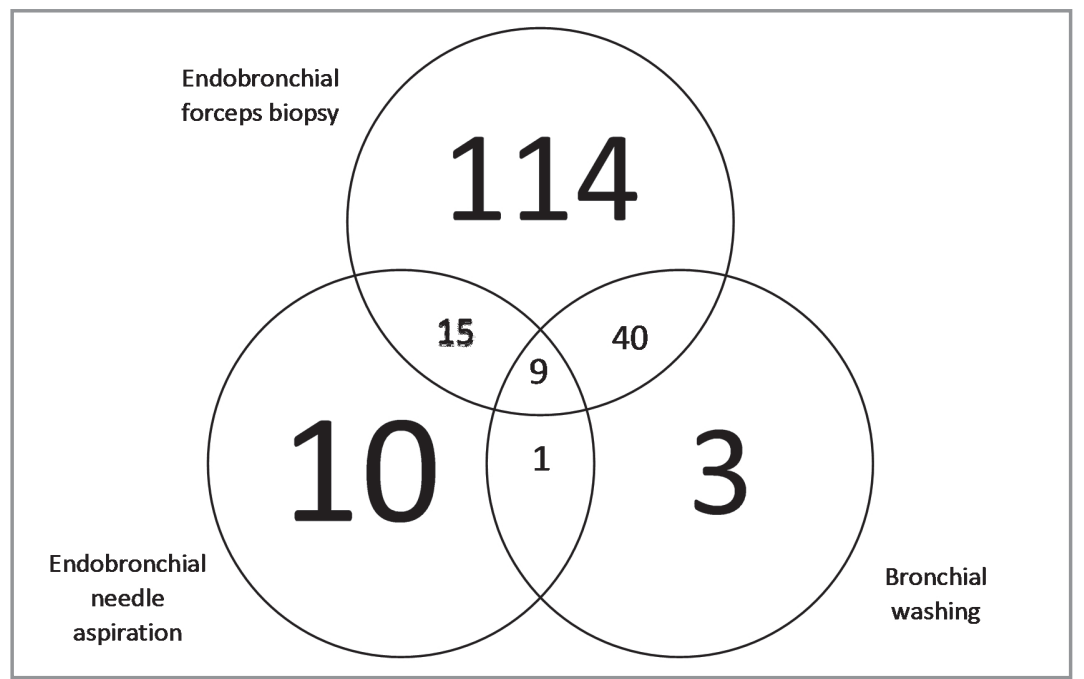

Figure 1. Distribution of positive pathological and/or cytological results for a malignant tumor according to performed bronchoscopic procedures.

BW cytology. Additionally, in 19 patients who had a repeated bronchoscopy for the same lesions, repeated collection of BW material cytology remained negative in all of the patients (12). Two other studies have also indicated that the addition of bronchial lavage to forceps biopsy has little or no diagnostic contribution and is not cost-effective $(3,16)$. In this study, only three patients $(1.1 \%)$ with undiagnostic biopsies had positive BW cytology revealing merely malignant epithelial cells. Although BWs appear to have contributed to a diagnosis of malignancy in three patients, additional diagnostic procedures (TruCut biopsies from iliac bone lesion and pulmonary mass, paracentesis) were performed for the exact diagnosis. Therefore, the added value of BW is negligible in this study. While two patients were diagnosed as adenocarcinoma, one patient was diagnosed as NSCLC. All three patients need additional pathological analysis for molecular targets such as epidermal growth factor receptor (EGFR), anaplastic lymphoma kinase (ALK), or ROS-1.

In recent years, novel techniques, liquid-based cytology (LBC) and cell block (CB) have been investigated in bronchial specimens to diagnose lung cancer in different studies. Although some studies claim that LBC has an increased diagnostic value compared to conventional cytology in the examination of BW(1719), some argue the opposite (20). LBC was also studied and found to be more effective than conventional cytology in terms of molecular assay, but these studies included not only BW but also bronchial brushings, TBNA, and pleural effusions. CB also has an increased diagnostic utility compared to conventional cytology $(19,21)$. Nevertheless, LBC and CB may hold promise as cytological methods in the diagnosis of lung cancer. However, they are still in the research phase and have not been implemented routinely in many centers.

In the changing epidemiology of lung cancer, adenocarcinomas became more prevalent in recent years $(22,23)$. In the present study, squamous cell carcinoma $(21.9 \%)$ was the most common histological subtype, followed by adenocarcinoma (17.5\%) and NSCLC (14.8\%). This finding can be explained by two main characteristics of our study subjects. First, we included visible tumors, which mean centrally located and prone to be squamous histology. Second, the ratio of NSCLC is high, probably due to small biopsies obtained by conventional FOB.

Surgery is the definitive treatment of lung cancer; however, most of the patients are diagnosed at locally advanced or advanced stages $(24,25)$. Understanding non-small cell lung cancer's molecular structure, a new era -personalized treatment- of lung cancer has begun(26). Therapies targeting EGFR mutations, ALK, and ROS-1 rearrangements are in use worldwide for patients who present with metastatic disease $(27,28)$. Immunotherapy is also a pioneer treatment modality in patients with tumors high expressing of PD-L1 (29). Determining new mutations with each passing day has led to an increase in the amount of tissue needed by the pathologists. 
The sensitivity of EBB employed for suspected lung cancer is reported to be $74 \%$, and $\geq 3$ biopsies are recommended for lung cancer diagnosis, and at least six biopsies can provide sufficient tissue for immunohistochemical analysis and molecular testing $(30,31)$. More recently, European Expert Group recommendations have advocated at least five forceps biopsies and additional five biopsies to maximize the volume of tissue (32). Taking histological biopsies is preferred over cytological washes. Considering these suggestions and analysis of our data, we gave up collecting BWs in patients with visible endobronchial lesions. Although there is no information about the ideal duration of bronchoscopy, it can be predicted that prolonging the procedure will increase complications. Considering the increased need for tissue, additional biopsies can be obtained in the time reserved for BW. Moreover, cytological examination of BW increases the procedure's cost (lavage traps, cytological examination) and the cytology department's workload for nothing.

The main limitation of the present study was its retrospective design. The macroscopic features of endobronchial lesions were defined based on bronchoscopy reports. The lack of data related to tumor size on computed tomography, location of the lesion that can affect the diagnostic yield of biopsy, and the number of biopsies were other limitations. On the other hand, real-life data of a reference center with a high number of patients are strengths of the present study.

In conclusion, in the era of personalized therapy, more biopsy materials have become crucial for molecular examination. It can be logical to obtain more biopsies in the time spent for BW. Therefore, abandoning routine collection of BWs during bronchoscopy procedure in patients with endobronchial lesions seems to be a cost and time-effective approach. Additionally, obtaining more tissues instead is vital for detailed immunohistochemistry and molecular testing.

\section{Main Points}

Whether or not collecting bronchial washing is necessary for the diagnosis of lung cancer is still controversial.

In the age of personalized treatment, more and more tissues are needed for molecular studies.

According to this study, only three of 269 patients diagnosed with bronchial washing while biopsy and endobronchial needle aspiration were non-diagnos- tic. These three patients underwent other invasive interventions to support the diagnosis.

Abandoning routine collection of bronchial washings during bronchoscopy procedure in patients with endobronchial lesions seems to be a cost and time-effective approach.

Ethical Committee Approval: The ethical approval for this study was obtained from Hacettepe University Non-invasive Clinical Research Ethics Committee (Decision No: GO 17/252-11, Date: 29.03.2017).

\section{CONFLICT of INTEREST}

The authors of this meta-analysis declare that they have no conflict of interest.

\section{AUTHORSHIP CONTRIBUTIONS}

Concept/Design: OK, SSU

Analysis/Interpretation: DK

Data acqusition: EK, ÜÖS

Writing: OK, DK

Clinical Revision: EB, SÖ

Final Approval: DK

\section{REFERENCES}

1. Govert JA, Kopita JM, Matchar D, Kussin PS, Samuelson WM. Cost-effectiveness of collecting routine cytologic specimens during fiberoptic bronchoscopy for endoscopically visible lung tumor. Chest 1996; 109(2): 451-6.

2. Jones A, Hanson I, Armstrong G, O'driscoll B. Value and accuracy of cytology in addition to histology in the diagnosis of lung cancer at flexible bronchoscopy. Respir Med 2001; 95(5): 374-8.

3. Karahalli E, Yilmaz A, Türker H, Özvaran K. Usefulness of various diagnostic techniques during fiberoptic bronchoscopy for endoscopically visible lung cancer: should cytologic examinations be performed routinely? Respiration 2001; 68(6): 611-4.

4. Popp W, Rauscher H, Ritschka L, Redtenbacher S, Zwick $H$, Dutz W. Diagnostic sensitivity of different techniques in the diagnosis of lung tumors with the flexible fiberoptic bronchoscope. Comparison of brush biopsy, imprint cytology of forceps biopsy, and histology of forceps biopsy. Cancer 1991; 67(1): 72-5.

5. Chaudhary BA, Yoneda K, Burki NK. Fiberoptic bronchoscopy: comparison of procedures used in the diagnosis of lung cancer. J Thorac Cardiovasc Surg 1978; 76(1): 33-7.

6. Lee HS, Kwon SY, Kim DK, Yoon HI, LEE SM, Lee JH, et al. Bronchial washing yield before and after forceps biopsy in patients with endoscopically visible lung cancers. Respirol 2007; 12(2): 277-82. 
7. Dobler CC, Crawford ABH. Bronchoscopic diagnosis of endoscopically visible lung malignancies: should cytological examinations be carried out routinely? Inter Med J 2009; 39(12): 806-11.

8. Mondoni $M$, Rinaldo $R$, Carlucci P, Terraneo $S$, Saderi $L$, Centanni $S$, et al. Bronchoscopic sampling techniques in the era of technological bronchoscopy. Pulmonology 2020 .

9. Lam W, So S, Hsu C, Yu D. Fibreoptic bronchoscopy in the diagnosis of bronchial cancer: comparison of washings, brushings and biopsies in central and peripheral tumours. Clin Oncol 1983; 9(1): 35-42.

10. Mak V, Johnston I, Hetzel M, Grubb C. Value of washings and brushings at fibreoptic bronchoscopy in the diagnosis of lung cancer. Thorax 1990; 45(5): 373-6.

11. Buccheri G, Barberis P, Delfino MS. Diagnostic, morphologic, and histopathologic correlates in bronchogenic carcinoma: a review of 1,045 bronchoscopic examinations. Chest 1991; 99(4): 809-14.

12. Girard P, Caliandro R, Seguin-Givelet A, Lenoir S, Gossot D, Validire $P$, et al. Sensitivity of cytology specimens from bronchial aspirate or washing during bronchoscopy in the diagnosis of lung malignancies: An update. Clin Lung Cancer 2017; 18(5): 512-8.

13. Govert JA, Dodd LG, Kussin PS, Samuelson WM. A prospective comparison of fiberoptic transbronchial needle aspiration and bronchial biopsy for bronchoscopically visible lung carcinoma. Cancer 1999; 87(3): 129-34.

14. Friedlaender A, Addeo A, Russo A, Gregorc V, Cortinovis D, Rolfo CD. Targeted therapies in early stage NSCLC: hype or hope? Int J Mol Sci 2020; 21(17): 6329.

15. Chen $R$, Manochakian $R$, James L, Azzouqa A-G, Shi $H$, Zhang $Y$, et al. Emerging therapeutic agents for advanced non-small cell lung cancer. J Hematol Oncol 2020; 13: 1-23.

16. Chau CH, Yew WW, Wong PC, Lee J, Wong CF. Usefulness of collecting routine cytologic specimens during fiberoptic bronchoscopy for endoscopically visible and nonvisible lung carcinoma. Chest 1997; 111(2): 522-3.

17. Thakur A, Bakshi P, Kaur G, Verma K. Liquid-based and conventional cytology for bronchial washings/bronchoalveolar lavages in the diagnosis of malignancy-An institutional experience. J Cytol 2017; 34(3): 127.

18. Kathiresan B, Iles S, Glinski L. Conventional cytology vs liquid based cytology in preparation of bronchial wash, does the later have potential advantages? Eur Respir Soc 2013; 4(3): 127-32.

19. Collins GR, Thomas J, Joshi N, Zhang S. The diagnostic value of cell block as an adjunct to liquid-based cytology of bronchial washing specimens in the diagnosis and subclassification of pulmonary neoplasms. Cancer Cytopathol 2012; 120(2): 134-41.

20. Nalwa A, Walia R, Singh V, Madan K, Mathur S, lyer V, et al. Comparison of conventional smear and liquid-based cytology preparation in diagnosis of lung cancer by bronchial wash and transbronchial needle aspiration. I Cytol 2018; 35(2): 94
21. Kakodkar UC, Vadala R, Mandrekar S. Utility of cell-block of bronchial washings in diagnosis of lung cancer-a comparative analysis with conventional smear cytology. JCDR 2016; 10(4): OC25.

22. Cruz CSD, Tanoue LT, Matthay RA. Lung cancer: epidemiology, etiology, and prevention. Clin Chest Med 2011; 32(4): 605-44

23. Herbst RS, Morgensztern D, Boshoff C. The biology and management of non-small cell lung cancer. Nature 2018; 553(7689): 446-54.

24. National Institute for Health and Clinical Excellence (NICE) GUTU. Lung cancer: diagnosis and management. 2019.

25. Planchard D, Popat S, Kerr K, Novello S, Smit E, Faivre-Finn $C$, et al. Metastatic non-small cell lung cancer: ESMO Clinical Practice Guidelines for diagnosis, treatment and follow-up. Ann Oncol 2018; 29: iv192-iv237.

26. Ettinger DS, Bepler G, Bueno R, Chang A, Chang IY, Chirieac $L R$, et al. Non-small cell lung cancer: Clinical Practice Guidelines in Oncology ${ }^{\mathrm{TM}}$. JNCCN 2006; 4(6): 548-82.

27. Lindeman NI, Cagle PT, Beasley MB, Chitale DA, Dacic S, Giaccone $G$, et al. Molecular testing guideline for selection of lung cancer patients for EGFR and ALK tyrosine kinase inhibitors: guideline from the College of American Pathologists, International Association for the Study of Lung Cancer, and Association for Molecular Pathology. I Thorac Oncol 2013; 8(7): 823-59.

28. Bergethon K, Shaw AT, Ou S-HI, Katayama R, Lovly CM, McDonald NT, et al. ROS1 rearrangements define a unique molecular class of lung cancers. J Clin Oncol 2012; 30(8): 863 .

29. Gandhi L, Rodríguez-Abreu D, Gadgeel S, Esteban E, Felip $E$, De Angelis F, et al. Pembrolizumab plus chemotherapy in metastatic non-small-cell lung cancer. N Eng / Med 2018; 378(22): 2078-92.

30. Rivera MP, Mehta AC, Wahidi MM. Establishing the diagnosis of lung cancer: Diagnosis and management of lung cancer: American College of Chest Physicians evidencebased clinical practice guidelines. Chest 2013; 143(5): e142S-e65S.

31. Ofiara L, Navasakulpong A, Ezer N, Gonzalez A. The importance of a satisfactory biopsy for the diagnosis of lung cancer in the era of personalized treatment. Curr Oncol 2012;19(Suppl 1): S16.

32. Dietel $M$, Bubendorf L, Dingemans A-MC, Dooms C, Elmberger G, García RC, et al. Diagnostic procedures for non-small-cell lung cancer (NSCLC): recommendations of the European Expert Group. Thorax 2016; 71(2): 177-84. 